\title{
Does leptin cause proximal gastric cancer in the obese? The role of serum leptin in the etiology of proximal gastric cancer.
}

\author{
Jagric $T^{1}$, Hladnik $G^{2}$, Kolaric $R^{2}$, Dugonik $M^{3}$, Homsak $E^{3}$
}

Running head: Leptin and proximal gastric cancer

1 Corresponding author: Clinical Department for Abdominal and General Surgery, University Clinical Center Maribor, Ljubljanska 5, Maribor 2000, Slovenia; e-mail: tomaz.jagric@gmail.com.

2 Clinical Department for Abdominal and General Surgery, University Clinical Center Maribor, Ljubljanska 5, Maribor 2000, Slovenia.

3 Department for Laboratory Diagnostics, University Clinical Center Maribor, Ljubljanska 5, Maribor 2000, Slovenia.

\section{Abstract}

Background: The aim of the present study was to determine the correlation between obesity, serum levels of leptin and proximal gastric cancer.

Methods: Sixty-four gastric cancer patients operated on with curative intent were included in the study. We determined the correlation between the preoperative serum levels of leptin and the tumor's location.

Results: Serum leptin levels were correlated significantly with the proximal third location $(p=0.04)$, gastric outlet obstructing tumors $(p<0.0001)$, CRP levels $(p=0.03)$ and BMI $(p<0.0001)$. Patients with high serum levels of leptin had significantly more intestinal types of gastric cancer $(p=0.033)$ and better differentiation compared to patients with low serum leptin levels $(p=0.009)$. The linear regression model determined the proximal tumor location (beta: 0.467; $p=0.045$ ), BMI (beta: 0.657; $p=0.001$ ), high preoperative serum albumin (beta: $0.563 ; p=0.016$ ) and the presence of pyloric stenosis (beta: $0.525 ; p=0.006$ ) as related significantly to serum leptin levels. The Cox proportional hazard model identified age (HR: $0.003 ; 95 \% \mathrm{Cl}: 0-0.794 ; \mathrm{p}=0.041$ ), preoperative serum levels of leptin (HR: $0.125 ; 95 \% \mathrm{Cl}: 0.018-0.887 ; p=0.037$ ) and the number of extracted LNs (HR: $0.001 ; 95 \% \mathrm{Cl}: 0-$ $0.677 ; p=0.038$ ) as independent prognostic factors.

Conclusions: Serum levels of leptin were significantly elevated in patients with proximal gastric cancer, suggesting that the leptin's effect might be due to its systemic secretion. This might explain the higher incidence of proximal gastric cancer in obese patients. Elevated serum leptin levels were an independent prognostic factor. 
Key words: serum leptin, proximal gastric cancer

\section{Introduction}

Obesity was confirmed as a risk factor for the development of many tumors [1, 2]. Many papers have reported that obese patients were at higher risk for developing proximal cancer [1, 2]. The rising incidence of proximal gastric cancer is a source of serious concern. It has a worse prognosis, and the treatment is associated with higher morbidity [3]. Additionally, the quality of life after proximal gastric cancer operations is worse compared to distal gastric cancer locations [3]. Numerous theories have been postulated how increased body weight might lead to proximal gastric cancer development. The proposed factors for proximal tumor development were the increased intra-abdominal pressure, abnormal gastric motility and bile reflux [4]. While reflux certainly causes dysplasia and metaplasia in the distal third of the esophagus leading to Barret's cancer, it does not explain the higher incidence of tumors in the proximal third of the stomach in obese patients [5-7].

It has been proposed that adipose derived factors might have a direct role in the tumor development of proximal gastric cancer. These so-called adipokines, secreted by adipose tissue, were linked to the development of numerous cancers [4, 8]. Adipokines include several important mediators, including leptin, adiponectin, resistin and omentin, and are generally involved primarily in energy balance homeostasis [5], but also produce a low-grade systemic inflammation with related increased risk for malignant cell transformation [5]. Specifically, leptin has been brought into focus due to its pleiotropic effects $[8,9]$. Leptin signals via the leptin receptor and increases proliferation, inhibits apoptosis, and stimulates migration and invasion [8,9]. While studies confirmed that leptin expression in gastric cancer cells was increased in proximal tumors $[8,9]$, no direct link could be yet confirmed between increased body weight, serum levels of leptin and cancer development in the proximal third of the stomach $[4,8,9]$.

The aim of the present study was to determine the correlation between obesity, serum levels of leptin and the proximal gastric cancer. Therefore, we compared the preoperative serum levels of leptin between patients operated on for gastric cancer, and determined the prognostic value of serum levels of leptin in gastric cancer patients.

\section{Methods}

\section{Patients}

Sixty-four consecutive patients operated on for gastric adenocarcinoma with curative intent between April 2019 and August 2021 were included in the study. All patients gave their informed consent before participating in the study. All patients were worked-up diagnostically with preoperative standard laboratory tests, a chest X-ray, an upper gastro-intestinal endoscopy, and Computer Tomography of the chest and abdomen. Demographic, anthropometric and clinical data were obtained from the participants. Patients were discussed on a Tumor Board. Patients eligible for perioperative treatment received 4 cycles of FLOT, consisting of docetaxel $(60 \mathrm{mg} / \mathrm{m} 2)$, oxaliplatin $(85 \mathrm{mg} / \mathrm{m} 2)$, leucovorin (200 $\mathrm{mg} / \mathrm{m} 2$ ) and 5 -fluorouracil $(2,600 \mathrm{mg} / \mathrm{m} 2$ as a $24 \mathrm{hr}$. infusion), all given on day 1 . This procedure was 
performed every 2 weeks, and surgery followed 3 weeks after completion of the chemotherapy. Patients received 4 cycles of FLOT postoperatively. Patients were operated on laparoscopically or open based, on the preference of the operating surgeon. The contraindications for laparoscopy were previous upper abdominal surgery, excluding laparoscopic cholecystectomy, a BMI of more than 30 $\mathrm{kg} / \mathrm{m} 2$, glaucoma, increased intracranial pressure, severe COPD, or asthma.

Patients were divided into three groups, depending on their tumor location, into upper third, middle third and lower third gastric cancer. The upper third was defined according to Siewert's classification of the cardia tumors [10], as the tumor location at the anatomical cardia was extending to $5 \mathrm{~cm}$ below the gastro-esophageal junction. The middle third was defined as tumors located $5 \mathrm{~cm}$ below the gastroesophageal junction to the incisura angularis of the gastric antrum. The lower third tumors were defined as tumors extending from the incisura angularis to the pylorus. Preoperatively, blood samples were collected from the patients to determine their preoperative serum leptin levels. The preoperative serum levels of leptin were compared between patients with tumors in the three gastric locations. The study protocol was reviewed and approved by the Institutional Ethics Committee of the University Clinical Center Maribor (UKC-MB-KME-45/20).

\section{Operations}

All surgery was performed according to the Japanese Gastric cancer guidelines JCGC [11]. Depending on the preoperative T stage, location of the tumor, the differentiation and the Lauren's classification, patients received either a subtotal or a total gastrectomy. A D2 lymph node dissection was performed in all cases except in early gastric cancer.

In the laparoscopic group patients were operated on by a single team experienced in laparoscopic gastric cancer surgery. The laparoscopic procedure has been described elsewhere [12, 13]. Briefly, the operations were performed in a highly standardized manner by the five port approach. The patients were in the decubitus position with the legs extended, with the surgeon and the first assistant on either side of the patient, and the second assistant between the legs. The intestinal continuity was performed with an Omega loop, or with Roux-en-Y reconstruction. The specimen was extracted trough a $5 \mathrm{~cm}$ to $8 \mathrm{~cm}$ mini-laparotomy. All laparoscopic procedures were performed in a totally laparoscopic fashion.

\section{Serum leptin determination}

Serum leptin levels were determined from blood samples taken before the operation. A Human Leptin Quantikine ELISA Kit (R\&D Systems, Bio-Techne Corporation, Minnesota, USA) was used for serum leptin determination. The procedure was performed as specified by the manufacturer. $100 \mu \mathrm{L}$ of Assay Diluent was added to each well. Next, $50 \mu \mathrm{L}$ of the sample was added to each well, covered with a plate sealer, and incubated at room temperature for 2 hours on a horizontal orbital microplate shaker. Each well was aspirated and washed. The process was repeated 3 times for a total of 4 washes. Then, $200 \mu \mathrm{L}$ of Conjugate was added to each well, covered with a new plate sealer, and incubated at room temperature for 2 hours on the shaker, aspirated and washed 4 times. $200 \mu \mathrm{L}$ of Substrate Solution was added to each well. Plasma samples were incubated at room temperature for 30 minutes on the benchtop. Finally, $50 \mu \mathrm{L}$ of Stop Solution was added to each well, and read at $450 \mathrm{~nm}$ within 30 minutes. 


\section{Statistical analysis}

Continuous variables were expressed as mean \pm Standard Deviation, or median (interquartile range) where appropriate. Discrete variables were presented as absolute values (percentages). The variables were tested for normality by means of the Shapiro-Wilks and Kolmogoroff-Smirnoff tests. The continuous data were compared with the one-way ANOVA test, Mann-Whitney's $U$ test and the $\chi^{2}$-test as appropriate. The cut-off serum leptin levels were determined with the ROC analysis. The correlation between the preoperative serum levels of leptin and the covariate was determined with the linear logistic model with stepwise-forward regression. The survival analysis was performed with the KaplanMeier method, the difference in survivals between groups was determined with the log-rang test. Significant prognostic variables were determined by the Cox proportional regression model. The $p$ value of less than 0.05 was selected as the level of significance. All data analysis was performed with the SPSS version 25 for Windows (IBM, New York, USA).

\section{Study end-points and definitions}

The main end-point of the study was to determine the correlation between preoperative serum levels of leptin and the tumor's location. Secondary end-points were the correlation between the BMI, preoperative serum levels of leptin and location, correlation between the preoperative serum levels of leptin and pathological tumor characteristics, and the prognostic impact of the preoperative serum leptin.

\section{Results}

\section{Patients}

Sixty-four patients were included in the study. The clinico-pathological characteristics of the patients are presented in Table 1. The characteristics of patients and their tumors are presented in Table 1. Patients were balanced according to age and sex. A similar proportion of patients received perioperative chemotherapy in all three groups. Patients with tumors in the upper third had a significantly higher BMI compared to other locations $\left(29 \pm 5 \mathrm{~kg} / \mathrm{m}^{2}\right.$ in the upper third compared to $26 \pm 3$ $\mathrm{kg} / \mathrm{m}^{2}$ and $25 \pm 2 \mathrm{~kg} / \mathrm{m}^{2}$ in the middle and lower thirds; $p=0.035$ ). There was no significant difference in the number of extracted LNs per operation, or the number of positive LNs between different tumor locations. Patients had similar tumor grades, the Lauren histological type and the TNM stage distribution in all three locations. The most prevalent TNM stage was T3NOMO. No significant difference was found in the presence of ulceration. Significantly more patients in the distal third had stenosanting tumors. There was a significant difference in the proportion of performed total and subtotal gastrectomies $(p<0.0001)$. In patients with their tumor in the proximal and middle thirds, the most prevalent operation was the total gastrectomy ( $85 \%$ and $95.7 \%$ respectively), while $60 \%$ of patients with their tumor in the distal third received a subtotal gastrectomy. The proportion of laparoscopic operations was similar between the three groups.

Table 1. Demographic and clinicopathological characteristics of patients.

\begin{tabular}{|l|l|l|l|l|l|}
\hline & All (64) & Upper third (20) & Middle third (24) & $\begin{array}{l}\text { Lower third } \\
(20)\end{array}$ & $p$ \\
\hline Age [years $\pm S D]$ & $69 \pm 17$ & $69 \pm 15$ & $67.5 \pm 14$ & $72.8 \pm 9$ & 0.335 \\
\hline Sex [n(\%)] & & & & & 0.509 \\
\hline
\end{tabular}




\begin{tabular}{|c|c|c|c|c|c|}
\hline $\begin{array}{l}\text { Male } \\
\text { Female }\end{array}$ & $\begin{array}{l}42(65.6) \\
22(34.4)\end{array}$ & $\begin{array}{l}14(70) \\
6(30)\end{array}$ & $\begin{array}{l}16(66.7) \\
8(33.3)\end{array}$ & $\begin{array}{l}12(60) \\
8(40)\end{array}$ & \\
\hline $\begin{array}{l}\text { Preoperative } \\
\text { serum leptin } \\
\text { [median(IQR)] }\end{array}$ & $52(92)$ & 91(141) & $39(41)$ & $65(84)$ & $0.035^{*}$ \\
\hline $\begin{array}{l}\text { BMI } \\
{\left[\mathrm{kg} / \mathrm{m}^{2} \pm \mathrm{SD}\right]}\end{array}$ & $26 \pm 1$ & $29 \pm 5$ & $26 \pm 3$ & $25 \pm 2$ & $0.019 *$ \\
\hline $\begin{array}{l}\text { Number of } \\
\text { extracted LNs } \\
{[n \pm S D]}\end{array}$ & $28 \pm 18$ & $20 \pm 10$ & $33 \pm 15$ & $26 \pm 15$ & 0.111 \\
\hline $\begin{array}{l}\text { Number of } \\
\text { positive LNs } \\
\text { [median(IQR)] }\end{array}$ & $1(5.5)$ & $1.5(6.5)$ & $2(3)$ & $1(8)$ & 0.703 \\
\hline $\begin{array}{l}\text { Serum CRP } \\
\text { POD1 } \\
{[\mathrm{g} / \mathrm{ml}(\mathrm{IQR})]}\end{array}$ & $51(58)$ & $51(29)$ & $57(32)$ & $61(77)$ & 0.912 \\
\hline $\begin{array}{l}\text { Preoperative } \\
\text { serum } \\
\text { haemoglobin } \\
{[\mathrm{g} / \mathrm{I} \pm \mathrm{SD}]}\end{array}$ & $116 \pm 24$ & $127 \pm 16$ & $125 \pm 12.5$ & $111 \pm 21$ & 0.180 \\
\hline $\begin{array}{l}\text { Preoperative } \\
\text { serum albumin } \\
{[\mathrm{g} / \mathrm{I} \pm \mathrm{SD}]}\end{array}$ & $34 \pm 6$ & $33 \pm 4$ & $37 \pm 3.5$ & $30 \pm 6$ & 0.231 \\
\hline $\begin{array}{l}\text { Proximal } \\
\text { border } \\
{[\mathrm{mm} \pm \mathrm{SD}]}\end{array}$ & $48 \pm 28$ & $23 \pm 13$ & $68 \pm 37$ & $70 \pm 48$ & $<0.0001^{*}$ \\
\hline $\begin{array}{l}\text { Distal border } \\
{[\mathrm{mm} \pm \mathrm{SD}]}\end{array}$ & $58 \pm 51$ & $111 \pm 50$ & $64 \pm 20$ & $39 \pm 30$ & $<0.0001^{*}$ \\
\hline $\begin{array}{l}\text { Perioperative } \\
\text { CT [n(\%)] } \\
\text { Yes } \\
\text { No }\end{array}$ & $\begin{array}{l}24(58.5) \\
17(41.5) \\
\end{array}$ & $\begin{array}{l}9(75) \\
3(25) \\
\end{array}$ & $\begin{array}{l}10(58.8) \\
7(41.2)\end{array}$ & $\begin{array}{l}5(41.7) \\
7(58.3)\end{array}$ & 0.102 \\
\hline $\begin{array}{l}\text { Laparoscopic } \\
\text { [n(\%)] } \\
\text { Open [n(\%)] }\end{array}$ & $\begin{array}{l}29(45.3) \\
35(54.7) \\
\end{array}$ & $\begin{array}{l}9(45) \\
11(55) \\
\end{array}$ & $\begin{array}{l}11(45.8) \\
13(54.2)\end{array}$ & $\begin{array}{l}9(45) \\
11(55) \\
\end{array}$ & 0.998 \\
\hline $\begin{array}{l}\text { Type of } \\
\text { operation } \\
\text { [n(\%)] } \\
\text { Non-resectable } \\
\text { GT } \\
\text { GST } \\
\end{array}$ & $\begin{array}{l}1(1.6) \\
47(74.6) \\
15(23.8) \\
\end{array}$ & $\begin{array}{l}1(5) \\
17(85) \\
2(10) \\
\end{array}$ & $\begin{array}{l}0(0) \\
22(95.7) \\
1(4.3) \\
\end{array}$ & $\begin{array}{l}0(0) \\
8(40) \\
12(60) \\
\end{array}$ & $<0.0001^{*}$ \\
\hline $\begin{array}{l}\text { Grade }[n(\%)] \\
\text { Good } \\
\text { Moderate } \\
\text { Poor }\end{array}$ & $\begin{array}{l}8(12.9) \\
19(30.6) \\
3(56.5)\end{array}$ & $\begin{array}{l}0(0) \\
6(31.6) \\
13(68.4)\end{array}$ & $\begin{array}{l}3(13) \\
7(30.4) \\
13(56.5)\end{array}$ & $\begin{array}{l}3(15) \\
6(30) \\
11(55)\end{array}$ & 0.174 \\
\hline $\begin{array}{l}\text { PNI [n(\%)] } \\
\text { Yes } \\
\text { No } \\
\end{array}$ & $\begin{array}{l}27(43.5) \\
35(56.5)\end{array}$ & $\begin{array}{l}11(57.9) \\
8(42.1)\end{array}$ & $\begin{array}{l}8(34.8) \\
15(65.2)\end{array}$ & $\begin{array}{l}8(40) \\
12(60)\end{array}$ & 0.271 \\
\hline $\begin{array}{l}\text { LVI }[n(\%)] \\
\text { Yes } \\
\text { No }\end{array}$ & $\begin{array}{l}32(51.6) \\
30(48.4)\end{array}$ & $\begin{array}{l}9(47.4) \\
10(52.6)\end{array}$ & $\begin{array}{l}13(56.5) \\
10(43.5)\end{array}$ & $\begin{array}{l}10(50) \\
10(10)\end{array}$ & 0.878 \\
\hline
\end{tabular}




\begin{tabular}{|c|c|c|c|c|c|}
\hline $\begin{array}{l}\text { Lauren }[\mathrm{n}(\%)] \\
\text { Intestinal } \\
\text { Diffuse } \\
\text { Mixed }\end{array}$ & $\begin{array}{l}35(55.6) \\
12(19) \\
16(25.4)\end{array}$ & $\begin{array}{l}11(55) \\
5(25) \\
4(20) \\
\end{array}$ & $\begin{array}{l}11(47.8) \\
6(26.1) \\
6(26.1)\end{array}$ & $\begin{array}{l}12(60) \\
2(10) \\
6(30)\end{array}$ & 0.653 \\
\hline $\begin{array}{l}\text { T [n(\%)] } \\
\text { Tis } \\
1 \mathrm{a} \\
1 \mathrm{~b} \\
2 \\
3 \\
4 \mathrm{a} \\
4 \mathrm{~b}\end{array}$ & $\begin{array}{l}2(3.2) \\
8(12.9) \\
7(11.3) \\
8(12.9) \\
19(30.6) \\
16(25.8) \\
2(3.2)\end{array}$ & $\begin{array}{l}0(0) \\
1(5.3) \\
3(13) \\
1(5.3) \\
8(42.1) \\
5(26.3) \\
1(5.3) \\
\end{array}$ & $\begin{array}{l}1(4.3) \\
3(13) \\
3(13) \\
3(13) \\
4(17.4) \\
8(34.8) \\
1(4.3) \\
\end{array}$ & $\begin{array}{l}1(5) \\
4(20) \\
1(5) \\
4(20) \\
7(35) \\
3(15) \\
0(0)\end{array}$ & 0.146 \\
\hline $\begin{array}{l}N[n(\%)] \\
0 \\
1 \\
2 \\
3 a \\
3 b\end{array}$ & $\begin{array}{l}30(48.4) \\
8(12.9) \\
12(19.4) \\
9(14.5) \\
3(4.8)\end{array}$ & $\begin{array}{l}11(57.9) \\
1(5.3) \\
5(26.3) \\
1(5.3) \\
1(5.3)\end{array}$ & $\begin{array}{l}10(43.5) \\
3(13) \\
4(17.4) \\
4(17.4) \\
2(8.7)\end{array}$ & $\begin{array}{l}9(43) \\
4(20) \\
3(15) \\
4(20) \\
0(0)\end{array}$ & 0.610 \\
\hline $\begin{array}{l}M[n(\%)] \\
0 \\
1 \\
\end{array}$ & $\begin{array}{l}60(96.8) \\
2(3.2)\end{array}$ & $\begin{array}{l}18(94.7) \\
1(5.3) \\
\end{array}$ & $\begin{array}{l}23(100) \\
0(0)\end{array}$ & $\begin{array}{l}19(95) \\
1(5) \\
\end{array}$ & 0.977 \\
\hline $\begin{array}{l}\text { Ulceration } \\
\text { [n(\%)] } \\
\text { Yes } \\
\text { No }\end{array}$ & $\begin{array}{l}48(77.4) \\
14(22.6)\end{array}$ & $\begin{array}{l}17(89.5) \\
2(10.5)\end{array}$ & $\begin{array}{l}16(69.6) \\
7(30.4)\end{array}$ & $\begin{array}{l}15(75) \\
5(25)\end{array}$ & 0.292 \\
\hline $\begin{array}{l}\text { Stenosis [n(\%)] } \\
\text { Yes } \\
\text { No }\end{array}$ & $\begin{array}{l}3(4.7) \\
61(95.3)\end{array}$ & $\begin{array}{l}0(0) \\
20(100)\end{array}$ & $\begin{array}{l}0(0) \\
24(100)\end{array}$ & $\begin{array}{l}3(15) \\
17(85)\end{array}$ & $0.026 *$ \\
\hline
\end{tabular}

BMI: Body Mass Index; LNs: Lymph Nodes; POD1: Post Operative Day 1; CT: Chemotherapy; GT: Total gastrectomy; GST: Subtotal gastrectomy; PNI: Perineural invasion; LVI: Lymphovascular invasion.

\section{Comparison of serum leptin levels between groups}

Patients in the upper third had significantly higher preoperative leptin levels compared to patients in the middle and lower thirds (Table 1). The serum levels of leptin were the highest in the proximal third (91(141)), followed by the patients with their lower third tumors (65(84)) and patients with middle third tumors (39(41)). The preoperative serum leptin levels were correlated significantly with the proximal third location $(p=0.04)$, gastric outlet obstructing tumors $(p<0.0001)$, CRP levels on the first postoperative day $(p=0.03)$ and BMI $(p<0.0001)$. When we excluded patients with gastric outlet obstructing tumors, patients with proximal tumors had still significantly higher preoperative serum leptin levels, while the serum levels between patients with middle and distal third tumors were similar.

Figure 1. Preoperative serum leptin levels in different tumor locations.

A) Preoperative serum leptin in upper, middle, lower third gastric cancers. 


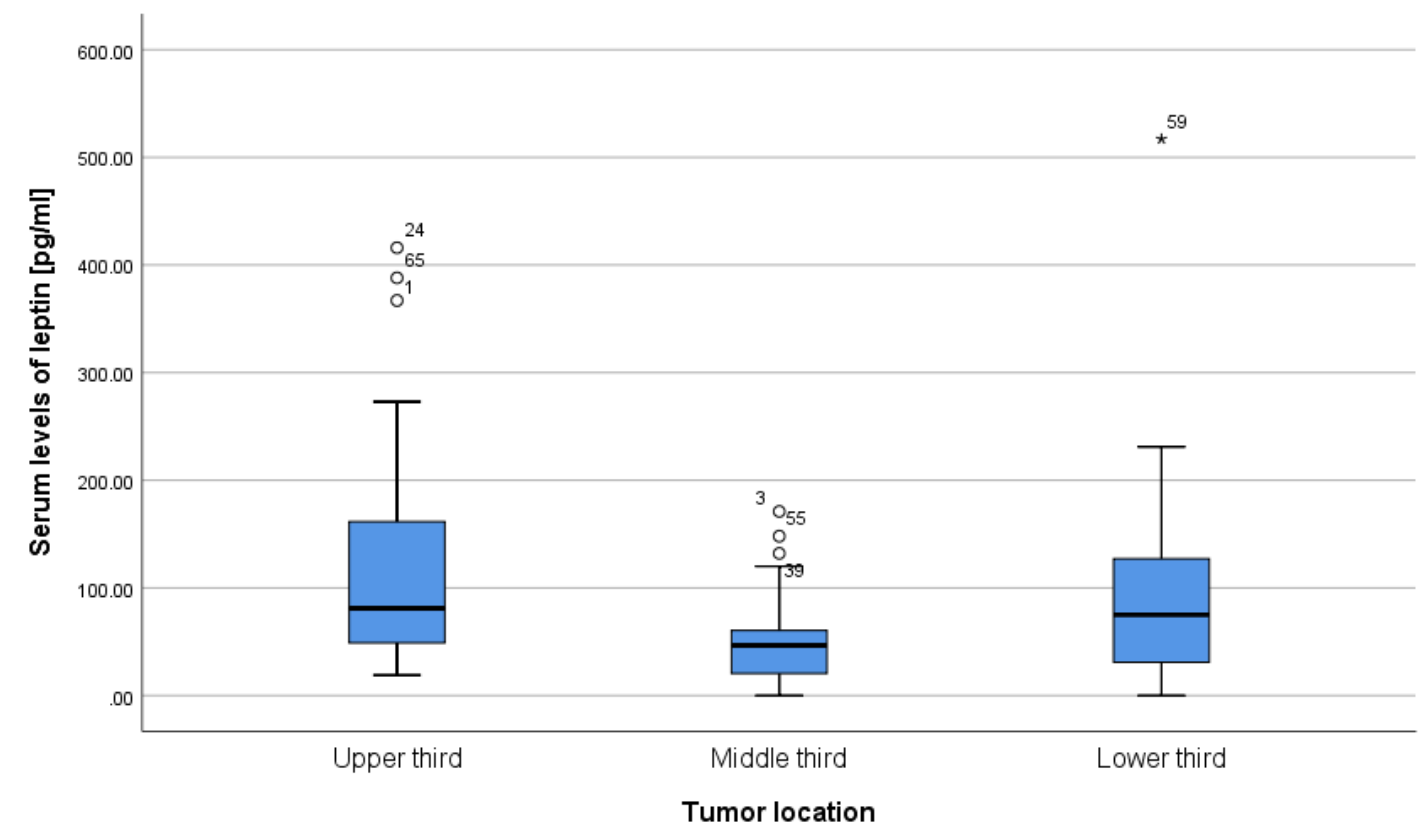

B)Preoperative serum leptin in upper, middle, lower third gastric cancer without obstructing tumors.

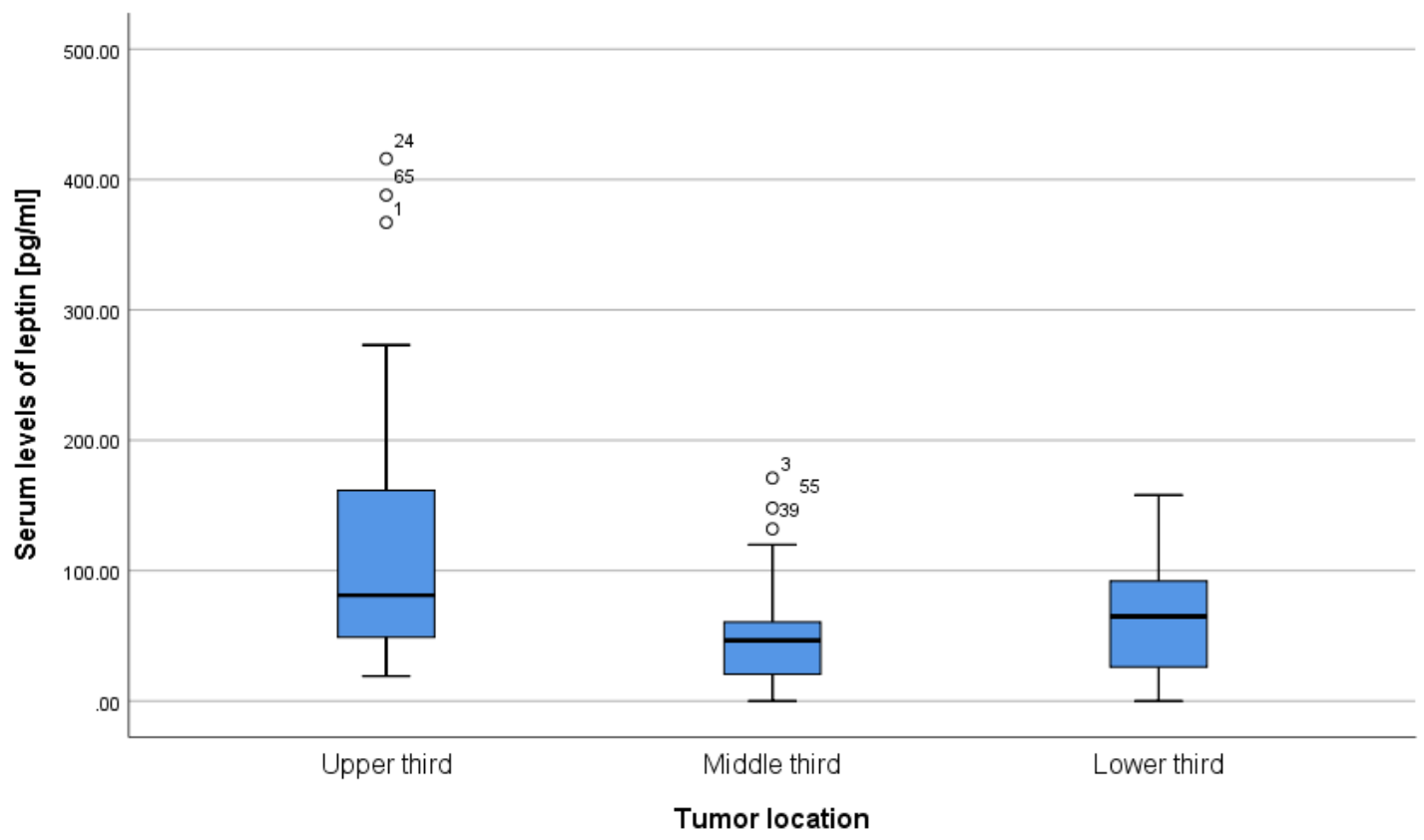

\section{Determination of the preoperative serum leptin cut-off}

Leptin was shown to be associated significantly with proximal tumor location. The ROC curve analysis was used to determine the preoperative serum level of leptin for the proximal third tumor location. The ROC curve identified leptin as associated significantly with the proximal third location (AUC = $0.702 ; p=0.011$ ). $115 \mathrm{ng} / \mathrm{ml}$ of serum leptin was selected for the cut-off.

Figure 2. ROC-analysis. 


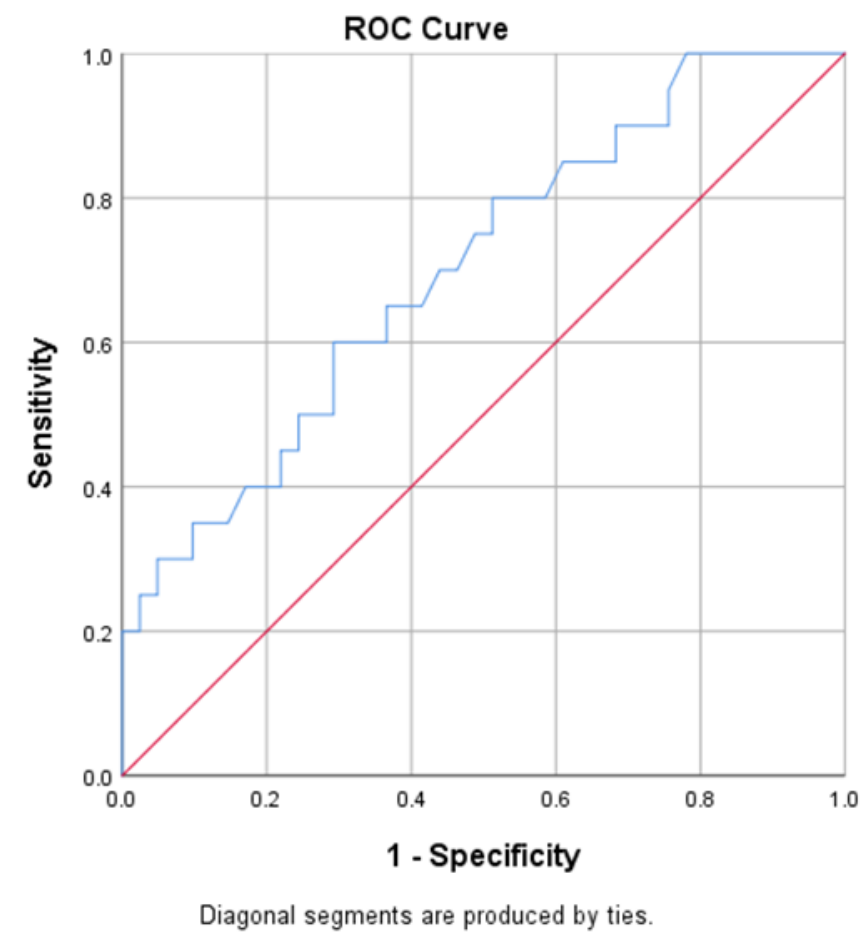

Subgroup analysis of patients with elevated preoperative serum leptin levels

Patients with high preoperative serum levels of leptin had a significantly higher BMI compared to patients with low preoperative serum leptine levels $\left(30 \pm 6 \mathrm{~kg} / \mathrm{m}^{2} \mathrm{vs} 25 \pm 3 \mathrm{~kg} / \mathrm{m}^{2} ; \mathrm{p}=0.002\right)$. Significantly fewer patients with higher preoperative serum levels of leptin recieved perioperative chemotherapy compared to patients with low leptin levels $(27.3 \%$ vs $70 \% ; p=0.018)$. Patients with gastric outlet obstructing tumours were much more common in the group of patients with low preoperative serum leptin levels $(27.3 \%$ vs $70 \% ; p=0.018)$. In patients with preoperative serum leptin levels the intestinal type of gastric cancer was most common ( $83 \%$ vs $51 \% ; p=0.033$ ). Patients with high preoperative serum leptin levels had significantly better and moderately differentiated tumors compared to low level patients ( $25 \%$ and $58.3 \%$ vs $10.6 \%$ and $25.5 \% ; p=0.009$ ).

Table 2. Comparison of patients with high and low preoperative serum levels of leptin.

\begin{tabular}{|c|c|c|c|}
\hline & \multicolumn{2}{|c|}{ Serum leptin concentration } & \multirow[t]{2}{*}{$p$} \\
\hline & $\begin{array}{l}\text { High }(>=115 \\
\mathrm{ng} / \mathrm{ml})(16)\end{array}$ & $\begin{array}{l}\text { Low }(<115 \\
\mathrm{ng} / \mathrm{ml})(47)\end{array}$ & \\
\hline Age [years $\pm S D$ ] & $68.9 \pm 10$ & $67.3 \pm 12$ & 0.678 \\
\hline $\begin{array}{l}\text { Sex }[n(\%)] \\
\text { Male } \\
\text { Female }\end{array}$ & $\begin{array}{l}14(70) \\
6(30)\end{array}$ & $\begin{array}{l}16(66.7) \\
8(33.3)\end{array}$ & 0.509 \\
\hline $\mathrm{BMI}\left[\mathrm{kg} / \mathrm{m}^{2} \pm \mathrm{SD}\right]$ & $30 \pm 6$ & $25 \pm 3$ & $0.002^{*}$ \\
\hline $\begin{array}{l}\text { Number of } \\
\text { extracted } L N s \\
{[n \pm S D]}\end{array}$ & $24 \pm 9$ & $27 \pm 14$ & 0.465 \\
\hline $\begin{array}{l}\text { Number of positive } \\
\text { LNs [median(IQR)] }\end{array}$ & 1(7) & $1(5)$ & 0.562 \\
\hline $\begin{array}{l}\text { Serum CRP POD1 } \\
{[\mathrm{g} / \mathrm{ml}(\mathrm{IQR})]}\end{array}$ & $51(29)$ & $57(32)$ & 0.639 \\
\hline
\end{tabular}




\begin{tabular}{|c|c|c|c|}
\hline $\begin{array}{l}\text { Preoperative serum } \\
\text { haemoglobin } \\
{[\mathrm{g} / \mathrm{I} \pm \mathrm{SD}]}\end{array}$ & $123 \pm 17$ & $122 \pm 17$ & 0.761 \\
\hline $\begin{array}{l}\text { Preoperative serum } \\
\text { albumin }[\mathrm{g} / \mathrm{I} \pm \mathrm{SD}]\end{array}$ & $34 \pm 2$ & $35 \pm 6$ & 0.638 \\
\hline $\begin{array}{l}\text { Proximal border } \\
{[\mathrm{mm} \pm \mathrm{SD}]}\end{array}$ & $63 \pm 41$ & $59 \pm 47$ & 0.792 \\
\hline $\begin{array}{l}\text { Distal border } \\
{[\mathrm{mm} \pm \mathrm{SD}]}\end{array}$ & $82 \pm 44$ & $72 \pm 42$ & 0.457 \\
\hline $\begin{array}{l}\text { Perioperative CT } \\
{[\mathrm{n}(\%)]} \\
\text { Yes } \\
\text { No }\end{array}$ & $\begin{array}{l}3(27.3) \\
8(72.7)\end{array}$ & $\begin{array}{l}21(70) \\
9(30)\end{array}$ & $0.018 *$ \\
\hline $\begin{array}{l}\text { Laparoscopic }[\mathrm{n}(\%)] \\
\text { Open }[\mathrm{n}(\%)]\end{array}$ & $9(56.3)$ & $20(41.7)$ & 0.234 \\
\hline $\begin{array}{l}\text { Type of operation } \\
\text { [n(\%)] } \\
\text { Non-resectable } \\
\text { GT } \\
\text { GST }\end{array}$ & $\begin{array}{l}1(6.3) \\
11(68.8) \\
4(25)\end{array}$ & $\begin{array}{l}0(0) \\
36(76.6) \\
11(23.4)\end{array}$ & 0.724 \\
\hline $\begin{array}{l}\text { Grade }[\mathrm{n}(\%)] \\
\text { Good } \\
\text { Moderate } \\
\text { Poor }\end{array}$ & $\begin{array}{l}3(25) \\
7(58.3) \\
2(16.7) \\
\end{array}$ & $\begin{array}{l}5(10.6) \\
12(25.5) \\
30(63.9)\end{array}$ & $0.009 *$ \\
\hline $\begin{array}{l}\text { PNI [n(\%)] } \\
\text { Yes } \\
\text { No }\end{array}$ & $\begin{array}{l}4(33.3) \\
8(66.7)\end{array}$ & $\begin{array}{l}21(44.7) \\
26(55.3)\end{array}$ & 0.355 \\
\hline $\begin{array}{l}\text { LVI }[\mathrm{n}(\%)] \\
\text { Yes } \\
\text { No }\end{array}$ & $\begin{array}{l}5(41.7) \\
7(58.3)\end{array}$ & $\begin{array}{l}25(53.2) \\
22(46.8) \\
\end{array}$ & 0.349 \\
\hline $\begin{array}{l}\text { Lauren }[\mathrm{n}(\%)] \\
\text { Intestinal } \\
\text { Diffuse } \\
\text { Mixed }\end{array}$ & $\begin{array}{l}11(83.6) \\
1(7.7) \\
1(7.7)\end{array}$ & $\begin{array}{l}24(51) \\
10(21.3) \\
13(27.7)\end{array}$ & $0.033^{*}$ \\
\hline $\begin{array}{l}\text { T }[n(\%)] \\
\text { Tis } \\
1 \mathrm{a} \\
1 \mathrm{~b} \\
2 \\
3 \\
4 \mathrm{a} \\
4 \mathrm{~b}\end{array}$ & $\begin{array}{l}1(8.3) \\
2(16.7) \\
0(0) \\
2(16.7) \\
3(25) \\
4(33.3) \\
0(0) \\
\end{array}$ & $\begin{array}{l}1(2.1) \\
6(12.8) \\
7(14.9) \\
5(10.6) \\
15(31.9) \\
11(23.4) \\
2(4.3)\end{array}$ & 0.636 \\
\hline $\begin{array}{l}N[n(\%)] \\
0 \\
1 \\
2 \\
3 a \\
3 b\end{array}$ & $\begin{array}{l}6(50) \\
1(8.3) \\
3(25) \\
1(8.3) \\
1(8.3)\end{array}$ & $\begin{array}{l}23(48.9) \\
6(12.8) \\
9(19.1) \\
7(14.9) \\
2(4.3)\end{array}$ & 0.919 \\
\hline $\begin{array}{l}M[n(\%)] \\
0 \\
1\end{array}$ & $\begin{array}{l}11(91.7) \\
1(8.3)\end{array}$ & $\begin{array}{l}46(97.9) \\
1(2.1)\end{array}$ & 0.368 \\
\hline
\end{tabular}




\begin{tabular}{|l|l|l|l|}
\hline Ulceration [n(\%)] & & & 0.3 \\
Yes & $8(66.7)$ & $37(78.7)$ & \\
No & $4(33.3)$ & $10(21.3)$ & \\
\hline Stenosis [n(\%)] & & & $0.018^{*}$ \\
Yes & $3(27.3)$ & $21(70$ & \\
No & $8(72.7)$ & $9(30)$ & \\
\hline
\end{tabular}

BMI: Body Mass Index; LNs: Lymph Nodes; POD1: Post Operative Day 1; CT: Chemotherapy; GT: Total gastrectomy; GST: Subtotal gastrectomy; PNI: Perineural invasion; LVI: Lymphovascular invasion.

\section{Multivariate analysis}

The linear regression model determined the proximal tumor location (beta: $0.467 ; p=0.045$ ), BMI (beta: 0.657; $p=0.001$ ), high preoperative serum albumin (beta: $0.563 ; p=0.016$ ) and the presence of pyloric stenosis (beta: $0.525 ; p=0.006$ ) as related significantly to preoperative serum leptin levels.

A binary logistic regression model was used to determine the odds of proximal tumor location for an increase of patients` BMI. The model predicted an odds increase of 1.373 for $1 \mathrm{~kg} / \mathrm{m}^{2}$ increase of BMI for the proximal third tumor location $(p=0.021)$.

\section{Survival analysis}

The mean observation period in the study was 7(10) months. During this time, 16 events (deaths) were recorded. Patients with high preoperative serum levels of leptin had significantly poorer long-term survival compared to patients with low preoperative serum levels of leptin $(p=0.028)$. One-year survival was $57.7 \%$ in the high preoperative serum leptin group, and $87.5 \%$ in the low preoperative serum leptin group.

Figure 3. Survival analysis in patients with high and low preoperative serum levels of leptin.

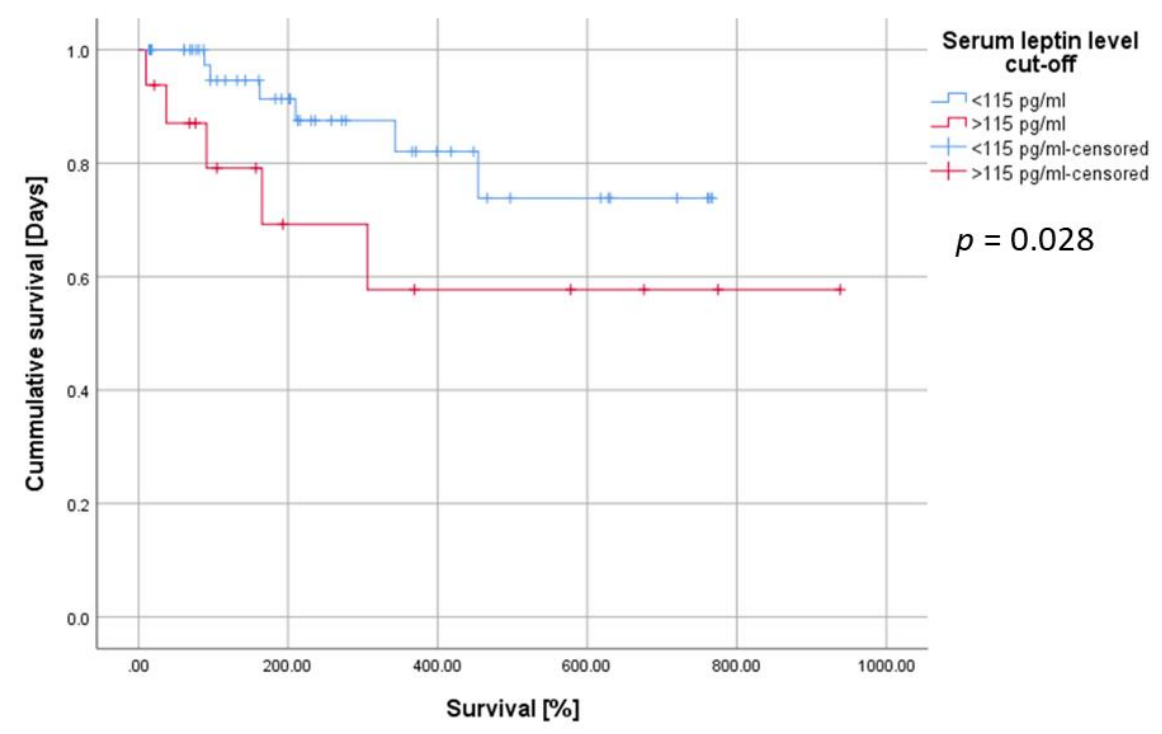

The Cox proportional hazard model identified age (HR: $0.003 ; 95 \% \mathrm{Cl}: 0-0.794 ; \mathrm{p}=0.041$ ), preoperative serum levels of leptin (HR: $0.125 ; 95 \% \mathrm{Cl}: 0.018-0.887 ; p=0.037$ ), and the total number of extracted LNs (HR: $0.001 ; 95 \% \mathrm{Cl}: 0-0.677 ; p=0.038$ ) as significant predictors for poor long-term prognosis. 


\section{Discussion}

In the present study we observed that gastric cancer patients with proximal tumors had significantly higher BMI compared to middle and distal third gastric cancer tumors. The patients in our study were 1.373 times more likely to develop gastric cancer in the proximal third for every increase of $1 \mathrm{~kg} / \mathrm{m}^{2}$ in their BMI.

There is mounting evidence that adipokines, especially leptin, might play a crucial role in the development of proximal gastric cancer [4-9]. Although expression of leptin in gastric cancer cells has been found to be increased in previous studies [8,9], the results on serum levels of leptin in gastric cancer patients are far from being so clear-cut. To date, researchers have failed to confirm that serum levels of leptin were related to proximal tumor locations in gastric cancer [14-16]. These conflicting results could be explained with the mixed patient population included in the studies [14-16]. Tas et al. included $24 \%$ of patients with an undetermined tumor location [16], while, in the study performed by Bulkabas et al., none of the patients had a known tumor location [14]. In addition, in the latter studies most of the patients had advanced and non-resectable gastric cancer suffering from cachexia. This might explain why no conclusive results could be produced. Patients with resectable gastric cancer were included in the present study. The multivariate linear regression model identified that proximal third tumors were related significantly to preoperative serum leptin levels. Since most of the cells expressing leptin receptors (Ob-R) are located in the lower gastric fundus, it is only natural to expect that leptin has the strongest effect on the cells located in these areas. Based on our observations, we propose that, in obese individuals, leptin secreted from non-gastric locations might be responsible for tumor development in the upper third of the stomach. We propose that the chronically elevated leptin levels derived from adipose tissue rather than leptin secreted by gastric cells may act systemically.

Leptin has a pleiotropic effect, and besides its role in energy metabolism and society, it is also known to stimulate proliferation in gastric cells [8-9]. It has been shown that it promotes proliferation of gastric cancer and tumor cells [17]. Leptin was proposed to be involved in the initial steps of gastric cancer development [17]. Previous studies have found a strong correlation between leptin expression in gastric cancer and tumor differentiation [17-19]. Zhao et al. have found that more differentiated tumors had a stronger intensity of leptin staining [9]. This phenomenon was observed in many growth factors related to tumor development, while, in later stages, growth factors are down regulated as the tumor dedifferentiates. In our study, patients with preoperative serum levels of leptin above $115 \mathrm{ng} / \mathrm{ml}$ were correlated significantly with good differentiation and Lauren intestinal histological type. This is in line with previous observations [8, 9, 17-19]. Nonetheless, we did not observe a relation of leptin with advanced stage, nodal metastases or distal metastases, as observed in other studies [17-19].

Our results confirmed that the preoperative serum levels of leptin were associated with the preoperative serum albumin levels. Serum albumin is a marker of nutritional state [20,21]. Leptin is elevated in well-fed patients. Consequently, the observed relationship between leptin and serum albumin could simply be a marker of the nutritional state of the patient.

Serum leptin was correlated significantly with gastric outlet obstructing tumors. Zhao et al. found that leptin is secreted from parietal and chief gastric cells as a response to local cell injury [9]. The secreted leptin acts as an autocrine cell growth factor, promoting cellular regeneration. Stomach dilatation caused by pyloric stenosis could, similarly, lead to increased local secretion of leptin from the fundal parietal and chief cells, leading to the increased serum levels observed in our study. 
The Cox regression model identified preoperative serum leptin as an independent prognostic factor. Patients with leptin serum levels above $115 \mathrm{ng} / \mathrm{ml}$ had significantly worse long-term survival compared to patients with lower leptin levels. This is in line with previous observations, where a significant correlation between leptin and advanced stages was found [17-19]. Gang et al. observed poorer survival in patients with higher serum leptin levels [19]. They suggested that the poorer long-term survival in leptin expressing tumors was related to the advanced stage [19]. Although we did not find a correlation between preoperative serum leptin levels and tumor stage, we agree with Gang et al. that leptin might be responsible for the higher invasiveness by down-stream activation of ERK-1 and STAT3 effectors responsible for tumor progression, ultimately leading to lymph node and distal metastases, and eventually to poorer long-term survival [17-19].

Our study has to be viewed in light of some limitations. The sample size was small, therefore, some correlations that might have become apparent on a larger sample did not reach the level of significance. Additionally, the observational period was relatively short. In the present study we determined the correlation of serum leptin with tumor location. Although we could confirm that leptin was associated with proximal gastric cancer tumors, to confirm the relation between increased body weight immunohistochemical expression of leptin in tumor cells and Western blot analysis of the phosphorylation of target receptors should have been determined indisputably as well. A heterogeneous group of patients was included, consisting of different stages. Finally, different factors promote leptin secretion which were not accounted for in our study.

In conclusion, our results confirm that serum levels of leptin were significantly in patients with proximal gastric cancer, suggesting that the leptin's effect might be due to its systemic secretion rather than by the local secretion from gastric cells. This might explain the higher incidence of proximal gastric cancer in obese patients. Higher preoperative serum levels of leptin were correlated with intestinal Lauren tumor type, with better differentiated tumors. We also found that elevated serum leptin levels are an independent prognostic factor. These results highlight the detrimental effects of obesity in gastric cancer patients.

Funding: None declared. This research received no external funding.

Acknowledgments: None declared.

Author Contributions: Each author is has made substantial contributions to the conception or design of the work, the acquisition, analysis, or interpretation of data, the creation of new software used in the work, has drafted the work or substantively revised it. The authors approved the submitted version and agree to be personally accountable for the author's own contributions and for ensuring that questions related to the accuracy or integrity of any part of the work, even ones in which the author was not personally involved, are appropriately investigated, resolved, and documented in the literature.

Institutional Review Board Statement: The study was conducted according to the guidelines of the Declaration of Helsinki. The study protocol was reviewed and approved by the Institutional Ethics Committee of the University Clinical Center Maribor (UKC-MB-KME-45/20). 
Informed Consent Statement: Informed consent was obtained from all subjects involved in the study. Written informed consent has been obtained from the patient(s) to publish this paper.

Data Availability Statement: Not aplicable.

Conflicts of Interest: The authors declare no conflict of interest.

\section{References}

1.Yang P, Zhou Y, Chen B, Wan HW, Jia GQ, Bai HL, Wu XT. Overweight, obesity and gastric cancer risk: Results from a meta-analysis of cohort studies. European journal of cancer, 2009; 45: 2867 - 2873. doi:10.1016/j.ejca.2009.04.019.

2.Li Q, Zhang J, Zhou Y, Qiao L. Obesity and gastric cancer. Frontiers in Bioscience, 2012; 17: 2383-2390.

3. Khan MR, Farooqi NB, Shahzad N. Is Proximal Gastric Cancer A Different Entity From Distal Gastric Cancer? Anatomical Site Distribution Of Signet Ring Cell Carcinoma And Its Association With Helicobacter Pylori Infection. J Ayub Med Coll Abbottabad, 2020; 32(2):194-197.

4. Li Q, Zhang J, Zhou Y, Qiao L. Obesity and gastric cancer. Frontiers in Bioscience, 2012; 7: 2383-2390.

5. Alexandre L, Long E, Beales ILP. Pathophysiological mechanisms linking obesity and esophageal adenocarcinoma. World J Gastrointest Pathophysiol, 2014; 5(4): 534-549. DOI: 10.4291/wjgp.v5.i4.534.

6. Elliott JA, Reynolds JV. Visceral Obesity, Metabolic Syndrome, and Esophageal Adenocarcinoma. Front. Oncol., 2021; 11: 1-15. https://doi.org/10.3389/fonc.2021.627270.

7. Elizabeth Long and Ian L.P. Beales. The role of obesity in oesophageal cancer development. Therapeutic Advances in Gastroenterology, 2014; 7(6) 247-268. DOI: 10.1177/1756283X14538689.

Receptorji

8. Ishikawa M, Kitayama J, Nagawa H. Expression pattern of leptin and leptin receptor (OB-R) in human gastric cancer. World J Gastroenterol, 2006; 12(34): 5517-5522.

9. Zhao L, Shen ZX, Luo HS, Shen L. Possible involvement of leptin and leptin receptor in developing gastric adenocarcinoma. World J Gastroenterol, 2005; 11(48):7666-7670.

10. Siewert JR, Stein HJ. Classification of adenocarcinoma of the oesophagogastric junction. Br J Surg, 1998; 85(11): 1457-9. doi: 10.1046/j.1365-2168.1998.00940.x.

11. Japanese Gastric Cancer Association. Japanese gastric cancer treatment guidelines 2014 (ver. 4). Gastric Cancer, 2017; 20(1):1-19. doi: 10.1007/s10120-016-0622-4.

12. Jagric T. The impact of modifying the laparoscopic lymphadenectomy technique on the extent of lymphadenectomy in laparoscopically operated gastric cancer patients. A single-center study. Surgery and Surgical Endoscopy, 2019; 1(1): 19-25. 
13. Jagric T. East meets West: the initial results of laparoscopic gastric cancer resections with Eastern principles in a single Western centre - a propensity score-matched study. Langenbecks Arch Surg, 2021. doi: 10.1007/s00423-021-02283-w.

14. Bolukbas FF, Kilic H, Bolukbas C, Gumus M, Horoz M, Turhal Nms, Kavakli B. Serum leptin concentration and advanced gastrointestinal cancers a case controlled study. BMC Cancer, 2004; 4(29): 1-4. DOI: $10.1186 / 1471-2407 / 4 / 29$.

15. Tuzun A, Uygun A, Yesilova Z, Ozel AM, Erdil A, Yaman H, Bagci S, Gulsen M, Karaeren N, Dagalp K. Leptin levels in the acute stage of ulcerative colitis. Journal of Gastroenterology and Hepatology, 2004; 19: 429-432.

16. Tas F, Karabulut $S$, Ertuk K, Duranyildiz D. Clinical significance of serum leptin level in patinets with gastric cancer. Eur. Cytokine Netw, 2018; 29(2): 52-8. DOI: 10.1684/ecn.2018.0408.

17. Isyraqiah F, Kutty MK, Durairajanayagam D, Salim N, Sigh H. Leptin induces the expression of tumorogenic genes in the gastric mucosa of male Sprague-Dawley rats. Experimentat Biology and Medicine, 2018; 243: 1118-1124. DOI: 10.1177/1535370218813909.

18. Pai R, Lin C, Tran T, Tarnawski A. Leptin activates STAT and ERK2 pathways and induces gastric cancer cell proliferation. Biochemical and Biophysical Research Communications, 2005; 331: 984-992. DOI: 10.10116/j.bbre.2005.03.236.

19. Gang Y, Wang J, Wang R, Wang K, Xu Y, Song G, Wu C, Yin Y. Leptin and HER-2 are associated with gastric cancer progression and prognosis of patients. Biomedicine and Pharmacotherapy, 2012; 66: 419-424. DOI: 10.1016/j.biopha.2012.03.002.

20. Bharadwaj S, Ginoya S, Gohel TD, Guirguis J, Vallabh H, Jevenn A, Hanouneh I. Malnutrition: laboratory markers vs nutritional assessment. Gastroenterology Report, 2016; 4(4): 272-280. DOI: 10.1093/gastro/gow013.

21. Cheong M, Chew STH, Oliver J, Baggs G, Low YL, How CH, Tan NC, Huynh DTT, Tey SL. Nutritional Biomarkers and Associated Factors in Community-Dwelling Older Adults: Findings from the SHIELD Study. Nutrients, 2020; 12(3329): 3-22. DOI:10.3390/nu12113329. 